\title{
Protein synthesis and breakdown and amino acid catabolism in protein-calorie malnutrition
}

By W. P. T. James, Clinical Nutrition and Metabolism Unit, Department of Human Nutrition, London School of Hygiene and Tropical Medicine, Keppel Street, London $W C_{I} E{ }_{7} H T$

As protein-calorie malnutrition (PCM) develops, the protein content of the body falls, despite the many mechanisms which operate to limit the further loss of nitrogen from the body (Waterlow, I968). Studies of the composition of children dying of PCM have shown that in both kwashiorkor and marasmus there is a reduction in total body protein to about two-thirds of the normal amount for a child of the same height (Garrow, Fletcher \& Halliday, I965).

This fall in body protein clearly results from an imbalance between synthesis and breakdown, but the effects will depend not only on the size of the imbalance, but also on the mass of protein involved and the rate at which the protein turns over. Collagen has a slower turnover-rate than most other proteins in the body, so that any discrepancy between its synthetic and breakdown rates will have little effect on collagen mass before malnutrition develops. This preservation of collagen tends to mask the large fall in non-collagen proteins to half their normal amounts (Picou, Halliday \& Garrow, i 966).

As the body loses protein, some tissues show a disproportionate loss in weight. Muscle mass in particular is reduced, so that it may amount in a marasmic child to less than a third of the normal. The fall in concentration of non-collagenous proteins in muscle also matches the fall in the protein content of liver, kidney and heart (Alleyne, Halliday, Waterlow \& Nichols, r969). Thus muscle, which in a healthy child contributes about $30 \%$ of total body protein, can be considered as a reserve tissue which can provide a large supply of essential amino acids for the rest of the body as well as substrates for gluconeogenesis.

\section{Total protein turnover}

It seems reasonable to suppose that there may be changes in the general rate of body-protein synthesis and breakdown when the protein intake is inadequate. In recent years the introduction of the technique of infusing radioactive-labelled amino acids has made it possible to measure synthesis and breakdown rates (Waterlow, 1969). If the rate at which an amino acid, such as lysine, moves in and out of the blood-stream is measured (the lysine flux) and the proportion of lysine in body protein is known, then we can obtain an estimate of total body protein turnover 
provided that other pathways for lysine metabolism are relatively unimportant and that the proteins being synthesized derive their lysine direct from the bloodstream.

Table I shows the calculated rate of protein turnover in young and adult rats infused with $\left[{ }^{14} \mathrm{C}\right]$ lysine and other amino acids. Although on a weight basis a rat weighing $100 \mathrm{~g}$ has a higher turnover-rate than a rat weighing $300 \mathrm{~g}$, the values are in fact very similar when related to the metabolic mass of the animal. Infusions of the three branched-chain amino acids in substrate quantities gave rather lower values for body-protein turnover, but infusions of tyrosine and the non-essential amino acid glycine have confirmed that the flux of these amino acids through the blood is in proportion to the relative amounts required for protein synthesis.

Table $\mathrm{r}$. The protein turnover-rates of growing and adult rats, r-year-old children, and adult man, measured by constant infusions of labelled amino acids

\begin{tabular}{|c|c|c|c|c|c|}
\hline \multirow[b]{2}{*}{ Reference } & \multirow{2}{*}{$\begin{array}{l}\text { Animal or } \\
\text { subject }\end{array}$} & \multirow{2}{*}{$\begin{array}{l}\text { Body-wt } \\
(\mathrm{kg})\end{array}$} & \multirow[b]{2}{*}{ Amino acid } & \multicolumn{2}{|c|}{ Protein turnover-rate } \\
\hline & & & & $(\mathrm{g} / \mathrm{kg})$ & $\left(\mathrm{g} / \mathrm{kg}^{0.73}\right)$ \\
\hline Waterlow \& Stephen, 1967 & Rat & 0.1 & {$\left[{ }^{14} \mathrm{C}\right]$ lysine } & 34 & $18 \cdot 3$ \\
\hline Garlick, r 969 & Rat & 0.1 & {$\left[{ }^{14} \mathrm{C}\right]$ glycine } & 45 & $24 \cdot 2$ \\
\hline Garlick (personal communication) & Rat & $0 \cdot 1$ & {$\left[{ }^{14} \mathrm{C}\right]$ tyrosine } & 42 & $22 \cdot 6$ \\
\hline Waterlow \& Stephen, I 967 & Rat & 0.3 & $\left.{ }^{14} \mathrm{C}\right]$ lysine & $2 I$ & $15 \cdot 2$ \\
\hline \multirow[t]{3}{*}{ Loftfield \& Harris, 1956} & Rat & 0.26 & {$\left[{ }^{14} \mathrm{C}\right]$ valine } & 33 & $\mathbf{2 2} \cdot 9$ \\
\hline & & 0.26 & {$\left[{ }^{14} \mathrm{C}\right]$ leucine } & $\mathrm{r} 3$ & $9 \cdot 0$ \\
\hline & & 0.26 & {$\left[{ }^{14} \mathrm{C}\right]$ isoleucine } & IZ & $8 \cdot 3$ \\
\hline \multirow[t]{2}{*}{ Picou \& Taylor-Roberts, I 969} & $\begin{array}{l}\text { Children, } \\
\text { malnourished }\end{array}$ & $5^{\cdot 1}$ & {$\left[{ }^{15} \mathrm{~N}\right]$ glycine } & $\operatorname{II} \cdot 2$ & $17 \cdot 4$ \\
\hline & $\begin{array}{l}\text { Children, } \\
\text { recovered }\end{array}$ & $7 \cdot 9$ & {$\left[{ }^{15} \mathrm{~N}\right]$ glycine } & $6 \cdot I$ & 10.7 \\
\hline Waterlow, 1967 & Man & 61 & {$\left[{ }^{14} \mathrm{C}\right]$ lysine } & $2 \cdot 6$ & $7 \cdot 9$ \\
\hline
\end{tabular}

All values calculated from specific activity or flux results from authors, together with amino acid content of whole body (Munro, I970). Lysine content taken as $4.45 \mathrm{mmol}$ lysine/g $\mathrm{N}$ (Waterlow \& Stephen, I 966).

Infusions of $\left[{ }^{15} \mathrm{~N}\right]$ glycine into I-year-old children gave similar values to those for adult man and the rat (Table $r$ ). Thus the concept of a defined rate of body-protein turnover as a general feature of metabolism, similar to that of the basal oxygen consumption (Waterlow, r968), seems to be upheld.

These calculations of protein turnover may be underestimates since they are based on the assumption that the labelled amino acid is incorporated into protein at the same specific activity as it had in blood. Tissue analysis in animals shows that the total intracellular specific activity may vary from half to three-quarters of that in blood because of the inflow of unlabelled amino acids from protein breakdown. Thus if the precursor site for incorporation of amino acids into protein is intracellular, the true protein turnover-rates may be as much as $50 \%$ higher than those listed in Table $\mathrm{I}$ for infusions of $\left[{ }^{14} \mathrm{C}\right]$ lysine, $\left[{ }^{14} \mathrm{C}\right]$ glycine and $\left[{ }^{14} \mathrm{C}\right]$ tyrosine.

A comparison of the rates for protein turnover with the minimum requirements for dietary protein shows that, at low intakes, the dietary protein may make only a small direct contribution to the daily flux of free amino acids in the body. It is not 
surprising therefore that there is very little change in lysine flux when animals are first put on a protein-free diet or even starved. Only after prolonged feeding with low-protein diets is there a fall in the flux of amino acids (Waterlow, 1968).

Picou \& Taylor-Roberts (1969), with intragastric infusion of $\left[{ }^{15} \mathrm{~N}\right]$ glycine in children who had recovered from malnutrition, also showed that increasing the protein intake to as much as four times the minimum requirements leads to little change in the rates of total body protein synthesis or breakdown. Measurements of protein turnover in malnourished children given the higher intakes, however, suggested a raised synthetic and breakdown rate. There may be a surge in turnover in a malnourished child with the renewed high intake of protein when treatment begins, but the disproportionate loss of the muscle proteins which turn over slowly will also enhance the values for protein turnover when expressed on a body-weight basis.

\section{Muscle protein turnover}

Although the turnover-rate of total body protein seems to be little affected by short-term fluctuations in dietary intake, animal experiments suggest that the development of PCM is accompanied by marked changes in the synthetic and breakdown rates of tissue proteins. We have shown with infusions of $\left[{ }^{14} \mathrm{C}\right]$ tryosine that there is a prompt fall in muscle protein synthesis once the inflow of amino acids and energy from food stops, and that fasting produces a further reduction in synthesis rates (Garlick, Millward and James, unpublished). Measurements by a different technique (Millward, I97०a,b) show that low-protein feeding does not produce such a profound fall in muscle protein synthesis as that seen in starvation, perhaps as a result of maintained circulating insulin levels in the animals fed on a carbohydrate diet.

These experimental findings are therefore in keeping with the suggestion that a key difference between kwashiorkor and marasmus is that in kwashiorkor there is a relative sequestration of amino acids in muscle, at the expense of liver and other tissues (Waterlow, Cravioto \& Stephen, I960; Whitehead \& Alleyne, I972). Moreover, in starvation there is a greater increase in muscle protein breakdown than in protein deprivation alone, so that more amino acids are available to the liver for protein synthesis and gluconeogenesis (Millward, 1970b). A young child, with a relatively smaller muscle mass than an adult, is thus more susceptible to illness from dietary deprivation. This is not merely because he is deprived of the nutrients needed for growth, but because he has a faster turnover-rate per $\mathrm{kg}$ than an adult, and a smaller proportion of muscle to buffer the effects of diet on essential organs such as the liver (Young, I970).

Growth in animals and man could be accomplished either by an increase in tissue synthesis or a reduction in the rate of tissue breakdown. Although the rise in oxygen consumption after a meal in children recovering from malnutrition has been interpreted as indicating a surge in protein synthesis (Ashworth, I969), direct measurements in animals recovering from malnutrition suggest that a major component in the growth spurt is a reduction in the rate of muscle-protein breakdown (Young, 
Stothers \& Vilaire, I971). During normal growth, however, we have shown that there is a significant relationship between the absolute rate of muscle-protein synthesis and the growth rate of young rats (Garlick, Millward and James, unpublished). Other tissue turnover-rates are unlikely to show this effect since they are much faster, and the growth component of total synthesis would be small. The evidence therefore suggests that muscle protein metabolism does alter significantly, particularly in response to starvation, but that this change is insufficient to produce an immediate measurable alteration in total body protein turnover. In the rat, muscle turnover accounts for about $25 \%$ of total body turnover.

\section{Liver protein turnover}

In malnutrition it is recognized that at least three serum proteins which originate in the liver circulate in reduced amounts: albumin, transferrin and the apoprotein of lipoproteins. The production of these proteins, derived from the synthetic apparatus of the bound ribosomes on the endoplasmic reticulum of the liver cell, may be under a different control from that of other intracellular proteins within the liver. Albumin synthesis falls promptly when the protein intake is reduced to levels just sufficient to maintain $\mathrm{N}$ balance (James \& Hay, I968), but two compensatory mechanisms operate to reduce the effects on the serum albumin concentration : there is a prompt contraction of the extravascular pool of albumin with transfer of albumin back into the blood-stream, and after a lag period of $2-3 \mathrm{~d}$, the breakdown rate of albumin drops to match the synthesis rate. At lower protein intakes compensation is inadequate and serum albumin concentrations fall (Kirsch, Frith, Black \& Hoffenberg, I 968 ). Liver perfusion experiments show that both starvation and protein deficiency lead to a reduction in albumin synthesis (Rothschild, Oratz, Mongelli \& Schreiber, I968; Hoffenberg, Gordon \& Black, 1971). Kirsch, Saunders, Frith, Wicht \& Brock (1969) suggest that in protein deficiency the synthesis rate may be affected by the depressed levels of circulating valine, leucine and isoleucine.

Perfusion studies also show that amino acid supply may be important for the synthesis of transferrin (Morgan \& Peters, 1971) and, since no compensatory mechanisms are known to operate, circulating transferrin concentrations may be more depressed than the albumin concentration in malnutrition (Antia, McFarlane \& Soothill, I968). A third circulating protein of liver origin, the apoprotein for lipoprotein synthesis and fat transport, also has a depressed synthesis rate in protein deficiency (A. Seakins, personal communication), thus contributing to the development of fatty liver and low serum triglyceride concentrations in kwashiorkor (Flores, Pak, Maccioni \& Monckeberg, I970).

The circulating amounts of the three proteins, albumin, transferrin and lipoprotein, are particularly low in kwashiorkor compared with marasmus, perhaps because of the limited availability of amino acids for the synthesis of 'export' proteins by the liver in protein deficiency. On the other hand, studies on the incorporation of labelled amino acids show that the fractional synthesis rate of liver cellular proteins is undiminished in animals fed on a low-protein diet (Waterlow \& Stephen, I968) or an amino acid mixture devoid of one essential amino acid 
(Sidransky \& Verney, 1970). The fall in liver weight and total liver protein results from an increase in the breakdown rate of proteins (Millward, 1970b), in part because of diminished stabilization of enzyme proteins by amino acids (Schimke, 1970).

\section{Metabolism and recycling of amino acids}

If the rate of total protein turnover in adult man is about $2.5 \mathrm{~g} / \mathrm{kg}$ per $\mathrm{d}$, this means that in a man weighing $60 \mathrm{~kg}$ about $\mathrm{I} 5 \circ \mathrm{g}$ protein are broken down each day. Since the daily obligatory $\mathrm{N}$ losses from the body, which have to be replaced are equivalent to only about $3 \circ \mathrm{g}$ protein (FAO/WHO, $\left.\mathrm{I}_{9} 6_{5}\right)$ it follows that $80 \%$ of the amino $\mathrm{N}$ produced by protein breakdown must be reutilized for synthesis. In the adult only $20 \%$ of the dietary protein requirement needs to be in the form of essential amino acids, which is only half the average essential amino acid content of tissue proteins. Therefore essential amino acids must be conserved even more efficiently than total amino $\mathrm{N}$, and probably about $90 \%$ of those produced by breakdown of body protein are reutilized. In children a higher proportion of essential amino acids are needed in the diet, since the laying down of new protein during growth requires a full complement of amino acids. It therefore seems possible that the limiting factor in the organism's ability to conserve $\mathrm{N}$ for maintenance and growth is the rate of destruction of the essential amino acids.

Catabolic enzymes for amino acid degradation often have a low affinity for their substrates, a factor which probably aids in the recycling of amino acids, but increasing concentrations of amino acids, such as tryptophan, do induce enzymes specific for their own catabolism, for example tryptophan pyrrolase, or even for the catabolism of other amino acids, for example the induction of serine dehydratase by tryptophan (Kaplan \& Pitot, I970).

The malnourished child is extremely efficient at conserving $\mathrm{N}$ and retains more than a normal child on equivalent intake. Both essential and non-essential amino acids were retained in greater than normal amounts by the marasmic children studied by Read, McLaren, Tchalian \& Nassar (1969) and Read, McLaren \& Tchalian (197I), although the over-all rates of excretion of the ${ }^{15} \mathrm{~N}$-labelled amino acids in these normal and marasmic children were surprisingly high. The same authors found that the malnourished children failed to conserve valine, which may explain why plasma valine concentrations are particularly low in protein-deficiency states. The other branched-chain amino acids, leucine and isoleucine, were conserved despite their being catabolized mainly by the peripheral tissues, for example by muscle rather than liver. Catabolism of leucine by liver mitochondria has been shown to fall in protein-deficient rats (McFarlane \& Holt, 1969), but perhaps of more importance is the fall in the activity of the decarboxylase enzyme required for the oxidation of the keto acid product of transamination in muscle (Sketcher, Fern and James, unpublished). In younger animals the ability to conserve the branchedchain amino acids is less well developed (Neale, 1971) and amino acid conservation may fail because of the need to use the carbon skeleton for energy and gluconeogenesis. 
Two further processes appear to favour the retention of $\mathrm{N}$ in protein deficiency. Amino acid-activating enzymes rise in concentration in the liver of malnourished children and protein-deficient animals, and urea-cycle enzymes fall (Stephen, I968; Stephen \& Waterlow, I968). These changes will tend to increase the likelihood of an amino acid becoming incorporated into protein rather than degraded with formation of urea.

Experimental evidence of adaptation in enzyme pathways for amino acid catabolism in protein deficiency has been matched by detailed analysis of metabolic blocks in amino acid degradation in kwashiorkor (Whitehead, I969). Reduced catabolism of histidine, phenylalanine and tyrosine, with accumulation of intermediates in the catabolic pathways, was only demonstrable, however, in severe cases of kwashiorkor. These changes, therefore, may have more pathological than adaptive significance.

Though experimental studies highlight the significance of some changes in protein metabolism in the malnourished subject, interpretation even from clinical studies must' be cautious. A malnourished child has often been through a combination of intermittent starvation and protein deficiency, as well as recurrent infections, before he finally presents with a variety of biochemical abnormalities. The interplay of infection, starvation and protein deficiency may be more important than any single factor in inducing the marked changes in metabolism and body composition.

I thank my colleagues in the Nutrition Department for their helpful comments and discussions, and P. J. Garlick for unpublished material.

\section{REFERENCES}

Alleyne, G. A. O., Halliday, D., Waterlow, J. C. \& Nichols, B. L. (1969). Br. F. Nutr. 23, 783.

Antia, A. V., McFarlane, H. \& Soothill, J. F. (1968). Archs Dis. Childh. 43, 459.

Ashworth, A. (1969). Nature, Lond. 223, 407.

FAO/WHO (1965). F.A.O. Nutr. Mtg Rep. Ser. no. 37 (and Tech. Rep. Ser. Wld Hlth Org. no. 301).

Flores, H., Pak, N., Maccioni, A. \& Monckeberg, F. (1970). Br. F. Nutr. 24, I005.

Garlick, P. J. (1969). Prac. Nutr. Soc. 28, 43A.

Garrow, J. S., Fletcher, K. \& Halliday, D. (1965). F. clin. Invest. 44, 4 I 7.

Horfenberg, R., Gordon, A. H. \& Black, E. G. (197I). Biochem. F. 122, 129.

James, W. P. T. \& Hay, A. M. (1968). F. clin. Invest. 47, 1958.

Kaplan, J. H. \& Pitot, H. C. (1970). In Mammalian Protein Metabolism Vol. 4, p. 387 [H. N. Munro, editor]. New York and London: Academic Press.

Kirsch, R., Frith, L., Black, E. \& Hoffenberg, R. (1968). Nature, Lond. 217, 579.

Kirsch, R., Saunders, S. J., Frith, L., Wicht, S. \& Brock, J. F. (1969). S. Afr. F. Med. 43, I25.

Loftfield, R. B. \& Harris, A. (1956). Y. biol. Chem. 219, I5 I.

McFarlane, I. G. \& Holt, C. von (I969). Biochem. F. IIx, 565.

Millward, D. J. (1970a). Clin. Sci. 39, 577.

Millward, D. J. (1970b). Clin. Sci. 39, 591 .

Morgan, E. H. \& Peters, T. (r97 I). F. biol. Chem. 246, 3500.

Munro, H. N. (editor) (1970). Mammalian Protein Metabolism Vol. 4, p. 299. New York and London: Academic Press.

Neale, R. J. (1971). Nature, New Biology 23x, I17.

Picou, D., Halliday, D. \& Garrow, J. S. (I966). Clin. Sci. 30, 345.

Picou, D. \& Taylor-Roberts, T. (r969). Clin. Sci. 36, 283.

Read, W. W. C., McLaren, D. S. \& Tchalian, M. (1971). Clin. Sci. 40, 375.

Read, W. W. C., McLaren, D. S., Tchalian, M. \& Nassar, S. (1969). F. clin. Invest, 48, I I43.

Rothschild, M., Oratz, M., Mongelli, J. \& Schreiber, S. S. (1968). 7. clin. Invest. 47, 2591. 
Schimke, R. T. (1970). In Mammalian Protein Metabolism Vol. 4, p. I77 [H. N. Munro, editor]. New York and London: Academic Press.

Sidransky, H. \& Verney, E. (1970). Am. J. clin. Nutr. 24, I 54.

Stephen, J. M. L. (1968). Br. F. Nutr. 22, I 53.

Stephen, J. M. L. \& Waterlow, J. C. (1968). Lancet i, I 18.

Waterlow, J. C. (1967). Clin. Sci. 33, 507.

Waterlow, J. C. (I 968). Lancet ii, Iogr.

Waterlow, J. C. (1969). In Mammalian Protein Metabolism Vol. 3, p. 36r [H. N. Munro, editor]. London and New York: Academic Press.

Waterlow, J. C., Cravioto, J. \& Stephen, J. M. L. (1960), Adv. Protein Chem. I5, 13 I.

Waterlow, J. C. \& Stephen, J. M. L. (1966). Br. Y. Nutr. 20, 46 ז.

Waterlow, J. C. \& Stephen, J. M. L. (1967). Clin. Sci. 33, 489 .

Waterlow, J. C. \& Stephen, J. M. L. (1968). Clin. Sci. 35, 287.

Whitehead, R. G. (r969). Proc. Nutr. Soc. 28, r.

Whitehead, R. G. \& Alleyne, G. A. O. (1972). Br. med. Bull. 28, 72.

Young, V. R. (1970). In Mammalian Protein Metabolism Vol. 4, p. $58_{5}$ [H. N. Munro, editor]. New York and London: Academic Press.

Young, V. R., Stothers, S. C. \& Vilaire, G. (1971). F. Nutr. x02, 1379. 